\title{
Synthesis, antimicrobial activity and absorption studies of some novel heterocyclic dyes based on 4-hexylbenzene-1,3-diol
}

\author{
Hitendra Mangubhai Patel \\ Department of Chemistry, Vithalbhai Patel and Rajratna Purushotamdas Tulsibhai Patel Science College, Sardar Patel University, Vallabh Vidyanagar, Gujarat, \\ 388120, India \\ *Corresponding author at: Department of Chemistry, Vithalbhai Patel and Rajratna Purushotamdas Tulsibhai Patel Science College, Sardar Patel University, Vallabh \\ Vidyanagar, Gujarat, 388120, India. Tel.: +91.982.4334922; fax: +91.982.4334922. E-mail address: shreeniketan71@yahoo.in (H.M. Patel).
}

\section{ARTICLE INFORMATION}

Received: 31 August 2011

Received in revised form: 12 October 2011

Accepted: 15 November 2011

Online: 31 March 2012

\section{KEYWORDS}

\section{Pyrazole}

Solvatochromism

Heterocyclic dyes

Antimicrobial activity

3-Aminocrotononitrile

4-Hexylbenzene-1,3-diol

\section{Introduction}

The growing interest in the pyrazole chemistry lies in designing new synthetic approach, theoretical calculations and applications of newer spectroscopic techniques. The usage of many pyrazole derivatives has undoubtedly created considerable attention in developing many different synthetic procedures in pharmaceuticals, agrochemicals, dyestuff. The recent developments in the synthetic routes and the chemistry of pyrazoles have been thoroughly reviewed [1-5]. The condensation of $\beta$-enaminonitriles and $\beta$-ketoesters with hydrazines continues to be the most widely used method for constructing the aminopyrazoles and pyrazolones, respectively $[6,7]$. The amino derivatives of pyrazoles belong to important compounds used for preparation of other functional derivatives mainly for the synthesis of condensed heterocyclic systems [812]. Also, fused pyrazoles are important compounds that have many derivatives with a wide range of interesting properties, such as antihyperglycemic, analgestic, anti-inflammatory, antipyretic, anti-bacterial, hypoglycaemic and sedative-hypnotic activities. Recently, some pyrazoles were reported to have nonnucleoside HIV-1 reverse transcriptase inhibitory activity [1315].

Some azopyrazole derivatives also find application in dyes, biological and pharmacological studies and complexes [16-18]. The use of heterocyclic intermediates in the synthesis of azo disperse dyes is well established and the resultant dyes exhibit good tinctorial strength and brighter dyeing than those derived from aniline-based diazo components. For instance, aminosubstituted thiazole, benzothiazole $[19,20]$ and benzoisothiazole [21] compounds afford highly electronegative diazo components and consequently, provide a pronounced bathochromic effect compared to the corresponding benzoid compounds. Moreover, azo disperse dyes containing 3-methyl-
$1 H$-pyrazole-5-one and 4-hexylbenzene-1,3-diol as coupling component have also been described as having red-violet colours in the literature [22-25].

We report here the synthesis of a series of new heterocyclic tetraazo dyes based on 4-hexylbenzene-1,3-diol. Antimicrobial activity and absorption ability of these dyes substituted with electron-withdrawing and electron-donating groups at their $o$-, $m$ - and $p$-position were also examined in detail.

\section{Experimental}

\subsection{Synthesis}

All the chemicals used for the synthesis of the compounds were obtained from various companies (commercial grade) and were further purified by crystallization. The solvents used were of spectroscopic grade.

IR spectra were determined using a Perkin-elmer Spectrum GX FT-IR model, on a KBr disc. Nuclear magnetic resonance $\left({ }^{1} \mathrm{H}\right.$ NMR) spectra were recorded on a Hitachi R-1500 in deuterated dimethylsulphoxide (DMSO- $d_{6}$ ) using tetramethylsilane (TMS) as the internal reference; chemical shifts were $(\delta)$ given in ppm. Ultraviolet- visible (UV-vis) absorption spectra were recorded on a Carl Zeiss UV/VIS Specord spectrometer at the wavelength of maximum absorption $\left(\lambda_{\max }\right)$ in a range of solvents, i.e. DMSO, DMF, acetonitrile, methanol, acetic acid and chloroform at the various concentrations $\left(1 \times 10^{-6}-1 \times 10^{-8} \mathrm{M}\right)$. Melting points were determined by open capillary method and are uncorrected. Elemental analysis was done on a Perkin Elmer CHNS/O Analyzer 2400 Series II were recorded on Agilent 1100 MSD.

2.1.1. Synthesis of 2-arylhydrazono-3-ketiminobutyronitriles (1a-1j) and 5-amino-4-arylazo-3-methyl-1H-pyrazoles (2a2j)

European Journal of Chemistry 

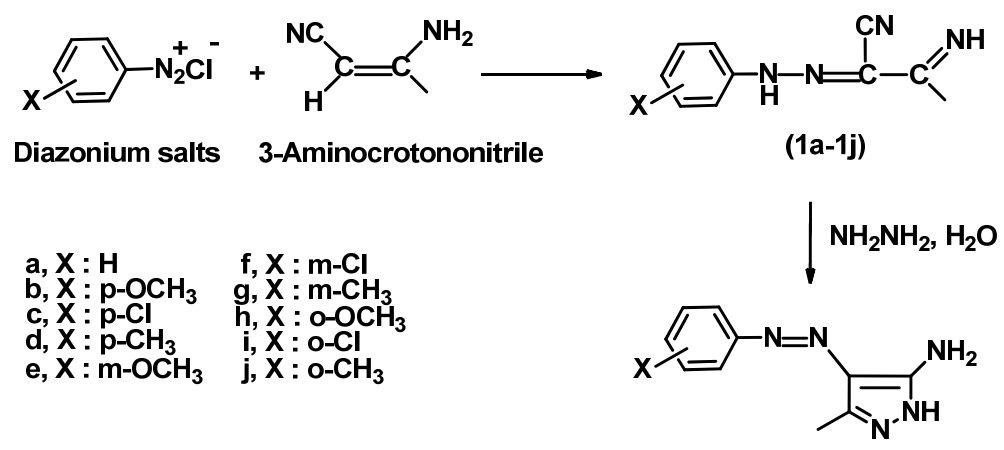

(2a-2j)

Scheme 1

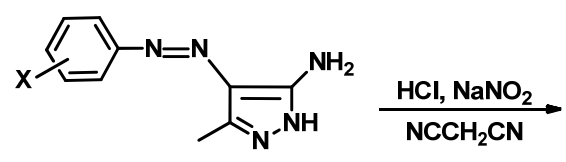

(2a-2j)

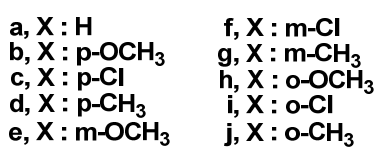

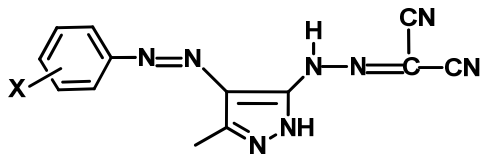

(3a-3j)

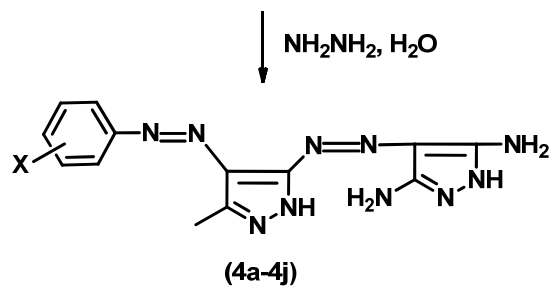

Scheme 2

2-Arylhydrazone-3-ketiminobutyronitriles (1a-1j) and 5amino-4-arylazo-3-methyl-1H-pyrazoles (2a-2j) were prepared according to the literature procedures [1,2]. The general route for the synthesis of 2-arylhydrazono-3ketiminobutyronitriles and 5-amino-4-arylazo-3-methyl- $1 \mathrm{H}$ pyrazoles is shown in (Scheme 1).

\subsubsection{Synthesis of pyrazolylhydrazonomalononitriles $3 a-3 j$}

5-Amino-4-arylazo-3-methyl- $1 \mathrm{H}$-pyrazoles $(0.01 \mathrm{~mol})$ were dissolved in a mixture of glacial acetic acid and concentrated hydrochloric acid $(20 \mathrm{~mL}$, ratio $1: 1)$ and the solution was then cooled to $273.15-278.15 \mathrm{~K}$. Sodium nitrite $(0.69 \mathrm{~g}, 0.01 \mathrm{~mol})$ in water $(10 \mathrm{~mL})$ was then added to this solution drop wise with vigorous stirring, during about $1 \mathrm{~h}$, while cooling at 273.15 $278.15 \mathrm{~K}$. Then the resulting diazonium solution was added in portions over $30 \mathrm{~min}$ to a vigorously stirred solution of malononitrile $(0.66 \mathrm{~g}, 0.01 \mathrm{~mol})$ in pyridine $(10 \mathrm{~mL})$ at between 273.15 and $278.15 \mathrm{~K}$, maintaining the $\mathrm{pH}$ at $7-8$ by simultaneous addition of sodium acetate solutions. The mixture was then stirred for $2 \mathrm{~h}$. at between 273.15 and $278.15 \mathrm{~K}$. The precipitated product separated upon dilution with water (50 $\mathrm{mL}$ ) was filtered off, washed with water several times, dried and crystallized from DMF- $\mathrm{H}_{2} \mathrm{O}$.

\subsubsection{Synthesis of heterocyclic disazo dyes $4 a-4 j$}

Equimolar amounts $(0.005 \mathrm{~mol})$ of $\mathbf{3 a}-\mathbf{3} \mathbf{j}$ and hydrazine monohydrate in ethanol $(30 \mathrm{~mL})$ were heated, under reflux, for $4 \mathrm{~h}$. The reaction mixture was concentrated in vacuo and then triturated with water whereby the resulting solid product was collected by filtration and crystallized from DMF- $\mathrm{H}_{2} \mathrm{O}$. The general route for the synthesis of disazo dyes $\mathbf{4 a - 4} \mathbf{j}$ is shown in (Scheme 2).

\subsubsection{Synthesis of heterocyclic tetraazo dyes $5 a-5 j$}

Diazotization of $\mathbf{4 a - 4 j}$ and coupling with 4-hexylbenzene1,3-diol were prepared according to the literature procedure [26]. The general route for the synthesis of heterocyclic tetraazo dyes $\mathbf{5 a - 5} \mathbf{j}$ is shown in (Scheme 3 ).

4-(3'-Methyl-4'-phenylazo-1'H-pyrazole-5'-ylazo)-3,5-[4,4'dihexyl-1,1'3,3'-tetrahydroxy-diphenylazo]-1H-pyrazole (5a): yellowish Orange. Yield: 77\%. M.p.: 186-187 ${ }^{\circ} \mathrm{C}$. FT-IR (KBr, cm 1): 3460, $3449(2 \mathrm{OH}), 3280,3203(2 \mathrm{NH}), 3086(\mathrm{Ar}-\mathrm{H}), 2991$ (Ar-H). ${ }^{1} \mathrm{H}$ NMR (400 MHz, DMSO- $\left.d_{6}, \delta, \mathrm{ppm}\right): 0.90\left(\mathrm{t}, 3 \mathrm{H}, \mathrm{CH}_{3}\right.$ ),1.31-1.59 (m, 6H, - $\left.\mathrm{CH}_{2}\right), 2.45\left(\mathrm{~s}, 3 \mathrm{H}, \mathrm{CH}_{3}\right), 2.62\left(\mathrm{~s}, 2 \mathrm{H},-\mathrm{CH}_{2}\right)$, $6.45(\mathrm{~s}, 1 \mathrm{H}, \mathrm{ArH}), 6.91(\mathrm{~s}, 1 \mathrm{H}, \mathrm{ArH}), 7.40-7.74(\mathrm{~m}, 5 \mathrm{H}, \mathrm{ArH}), 8.2$ (s, 1H, Ar-OH), 10.5 (s, 1H, Ar-OH), 11.15 (b,1H, NH),12.61 (b, $1 \mathrm{H}, \mathrm{NH}$ ). Anal. calcd. for $\mathrm{C}_{37} \mathrm{H}_{44} \mathrm{O}_{4} \mathrm{~N}_{12}$ : C, 61.60; $\mathrm{H}, 6.10 ; \mathrm{N}, 23.33$. Found: C, 61.51; H, 5.98; N, 23.28\%.

4-[3'-Methyl-4'-(p-methoxyphenylazo)-1'H-pyrazole-5'ylazo]-3,5-[4,4'-dihexyl-1,1',3,3'-tetrahydroxy-diphenylazo]-1Hpyrazole (5b): Red. Yield: 81\%. M.p.: 167-168 ${ }^{\circ} \mathrm{C}$. FT-IR (KBr, $\left.\mathrm{cm}^{-1}\right)$ : 3462, $3453(2 \mathrm{OH}), 3284,3197(2 \mathrm{NH}), 3094(\mathrm{Ar}-\mathrm{H})$, 2986 (Ar-H). ${ }^{1} \mathrm{H}$ NMR (400 MHz, DMSO- $\left.d_{6}, \delta, \mathrm{ppm}\right): 0.90(\mathrm{t}, 3 \mathrm{H}$, $\left.\mathrm{CH}_{3}\right), 1.31-1.59\left(\mathrm{~m}, 6 \mathrm{H},-\mathrm{CH}_{2}\right), 2.45\left(\mathrm{~s}, 3 \mathrm{H}, \mathrm{CH}_{3}\right), 2.62(\mathrm{~s}, 2 \mathrm{H},-$ $\left.\mathrm{CH}_{2}\right), 6.45(\mathrm{~s}, 1 \mathrm{H}, \mathrm{ArH}), 6.91(\mathrm{~s}, 1 \mathrm{H}, \mathrm{ArH}), 7.40-7.74(\mathrm{~m}, 5 \mathrm{H}$ $\mathrm{ArH}), 8.2$ (s, 1H, Ar-OH), 10.5 (s, 1H, Ar-OH), 11.15 (b,1H, $\mathrm{NH}), 12.61(\mathrm{~b}, 1 \mathrm{H}, \mathrm{NH})$. Anal. calcd. for $\mathrm{C}_{38} \mathrm{H}_{46} \mathrm{O}_{5} \mathrm{~N}_{12}: \mathrm{C}, 60.80 ; \mathrm{H}$ 6.10; N, 22.41. Found: C, 60.20; H, 6.88; N, 22.37\%.

4-[3'-Methyl-4'-(p-chlorophenylazo)-1'H-pyrazole-5'-ylazo]3,5-[4,4'-dihexyl-1,1'3,3'-tetrahydroxy-diphenylazo]-1H-pyrazole (5c): Reddish Brown. Yield: 84\%. M.p.: 249-250 ㄷ. 


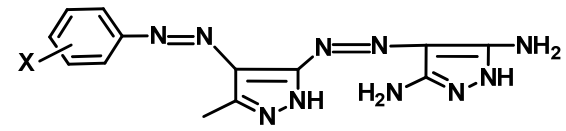

$(4 a-4 j)$
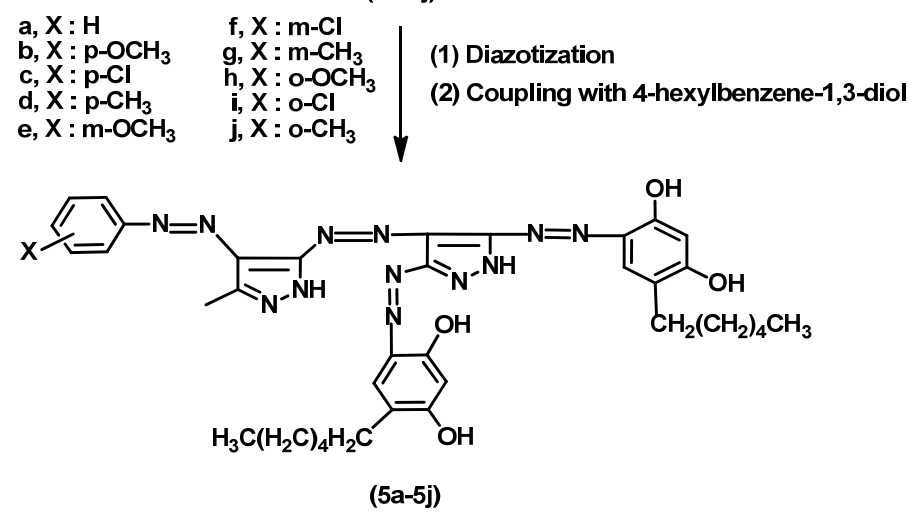

Scheme 3

FT-IR (KBr, cm-1): 3480, $3460(2 \mathrm{OH}), 3276,3169$ (2 NH), 3090 (Ar- H), $2994(\mathrm{Ar}-\mathrm{H}) .{ }^{1} \mathrm{H}$ NMR (400 MHz, DMSO- $\left.d_{6}, \delta, \mathrm{ppm}\right)$ : $0.90\left(\mathrm{t}, 3 \mathrm{H}, \mathrm{CH}_{3}\right), 1.31-1.59\left(\mathrm{~m}, 6 \mathrm{H},-\mathrm{CH}_{2}\right), 2.45(\mathrm{~s}, 3 \mathrm{H}, \mathrm{CH} 3)$, $2.62\left(\mathrm{~s}, 2 \mathrm{H},-\mathrm{CH}_{2}\right), 6.45$ (s, $\left.1 \mathrm{H}, \mathrm{ArH}\right), 6.91(\mathrm{~s}, 1 \mathrm{H}, \mathrm{ArH}), 7.40-7.74$ (m, 5H, ArH), 8.2 (s, 1H, Ar-OH), 10.5 (s, 1H, Ar-OH), 11.15 (b, $1 \mathrm{H}, \mathrm{NH}), 12.61$ (b, $1 \mathrm{H}, \mathrm{NH}$ ). Anal. calcd. for $\mathrm{C}_{37} \mathrm{H}_{43} \mathrm{O}_{4} \mathrm{~N}_{12} \mathrm{Cl}$ : C, 58.88; H, 5.71; N, 22.28. Found: C, 58.82; H, 5.69; N, 22.23\%. 4-[3'-Methyl-4'-(p-methylphenylazo)-1'H-pyrazole-5'-ylazo]3,5-[4,4'-dihexyl-1,1',3,3'-tetrahydroxy-diphenylazo]-1H-pyrazole (5d): Yellow Brown. Yield: $62 \%$. M.p.: $275^{\circ} \mathrm{C}$. FT-IR $\left(\mathrm{KBr}, \mathrm{cm}^{-1}\right)$ : 3491, 3480 (2 OH), 3289, 3200 (2 NH), 3022 (Ar-H), 2985 (ArH). ${ }^{1} \mathrm{H}$ NMR $\left(400 \mathrm{MHz}, \mathrm{DMSO}-d_{6}, \delta, \mathrm{ppm}\right): 0.88\left(\mathrm{t}, 3 \mathrm{H}, \mathrm{CH}_{3}\right.$ ),1.26-1.79 (m, $\left.2 \mathrm{H}, \mathrm{CH}_{2}\right), 2.40\left(\mathrm{~s}, 3 \mathrm{H}, \mathrm{CH}_{3}\right), 2.76\left(\mathrm{~s}, 3 \mathrm{H}, \mathrm{p}-\mathrm{CH}_{3}\right)$, 7.35-7.73 (dd, 4H, ArH), 8.9 (s, 1H, Ar-OH), 10.9 (s, 1H, Ar-OH), 9.30 (b, $1 \mathrm{H}, \mathrm{NH}), 10.23$ (b, $1 \mathrm{H}, \mathrm{NH})$. Anal. calcd. for $\mathrm{C}_{38} \mathrm{H}_{46} \mathrm{O}_{4} \mathrm{~N}_{12}$ : C, 62.10; H, 6.23; N, 22.28. Found: C, 61.92; H, 6.18; N, 22.82\%. 4-[3'-Methyl-4'-(m-methoxyphenylazo)-1'H-pyrazole-5'ylazo]-3,5-[4,4'-dihexyl-1,1',3,3'-tetrahydroxy-diphenylazo]-1Hpyrazole (5e): Yellowish. Yield: 78\%. M.p.: 168-169 ${ }^{\circ} \mathrm{C}$. FT-IR $\left(\mathrm{KBr}, \mathrm{cm}^{-1}\right): 3464,3450(2 \mathrm{OH}), 3294,3203(2 \mathrm{NH}), 3101$ (ArH), 2978 (Ar-H). ${ }^{1} \mathrm{H}$ NMR (400 MHz, DMSO- $\left.d_{6}, \delta, \mathrm{ppm}\right): 0.85(\mathrm{t}$, $\left.3 \mathrm{H}, \mathrm{CH}_{3}\right), 1.31-1.68\left(\mathrm{~m}, 2 \mathrm{H}, \mathrm{CH}_{2}\right), 2.46\left(\mathrm{~s}, 3 \mathrm{H}, \mathrm{CH}_{3}\right), 3.82(\mathrm{~s}, 3 \mathrm{H}$, $\left.\mathrm{m}-\mathrm{OCH}_{3}\right), 6.98-7.44(\mathrm{~m}, 4 \mathrm{H}, \mathrm{ArH}), 8.4(\mathrm{~s}, 1 \mathrm{H}, \mathrm{Ar}-\mathrm{OH}), 11.0(\mathrm{~s}, 1 \mathrm{H}$, Ar-OH), 11.16 (b, 1H, NH), 12.63 (b, 1H, NH). Anal. calcd. For $\mathrm{C}_{38} \mathrm{H}_{46} \mathrm{O}_{5} \mathrm{~N}_{12}$ : C, 60.80; H, 6.10; N, 22.40. Found: C, 60.60; $\mathrm{H}$, $6.01 ; \mathrm{N}, 22.10 \%$.

4-[3'-Methyl-4'-(m-chlorophenylazo)-1'H-pyrazole-5'-ylazo]3,5-[4,4'-dihexyl-1,1',3,3'-tetrahydroxy-diphenylazo]-1H-pyrazole (5f): Red. Yield: $81 \%$. M.p.: $224-225^{\circ} \mathrm{C}$. FT-IR $\left(\mathrm{KBr}, \mathrm{cm}^{-1}\right)$ : 3482 , 3459 (2 OH), 3275, $3144(2 \mathrm{NH}), 3069(\mathrm{Ar}-\mathrm{H}), 2963$ (Ar-H). ${ }^{1} \mathrm{H}$ NMR $\left(400 \mathrm{MHz}, \mathrm{DMSO}-d_{6}, \delta, \mathrm{ppm}\right): 0.89\left(\mathrm{t}, 3 \mathrm{H}, \mathrm{CH}_{3}\right), 1.33-1.89$ $\left(\mathrm{m}, 2 \mathrm{H}, \mathrm{CH}_{2}\right), 2.44\left(\mathrm{~s}, 3 \mathrm{H}, \mathrm{CH}_{3}\right), 7.45-7.70(\mathrm{~m}, 4 \mathrm{H}, \mathrm{ArH}), 8.7(\mathrm{~s}$, 1H, Ar-OH), 11.2 (s, 1H, Ar-OH), 11.13 (b, 1H, NH), 12.68 (b,1H, $\mathrm{NH}$ ). Anal. calcd. for $\mathrm{C}_{37} \mathrm{H}_{43} \mathrm{O}_{4} \mathrm{~N}_{12}$ : C, 58.88; $\mathrm{H}, 5.70 ; \mathrm{N}, 22.28$. Found: C, 58.81; H, 5.60; N, 22.22\%.

4-[3'-Methyl-4'-(m-methylphenylazo)-1'H-pyrazole-5'-ylazo]3,5-[4,4'-dihexyl-1,1',3,3'-tetrahydroxy-diphenylazo]-1H-

pyrazole (5g): Red. Yield: 73\%. M.p.: 190-191 ${ }^{\circ} \mathrm{C}$. FT-IR (KBr, $\left.\mathrm{cm}^{-1}\right):$ 3494, $3483(2 \mathrm{OH}), 3276,3206(2 \mathrm{NH}), 3078(\mathrm{Ar}-\mathrm{H})$, 2966 (Ar-H). ${ }^{1} \mathrm{H}$ NMR (400 MHz, DMSO- $\left.d_{6}, \delta, \mathrm{ppm}\right): 0.85$ (t, 3H, $\left.\mathrm{CH}_{3}\right), 1.37-1.79\left(\mathrm{~m}, 2 \mathrm{H}, \mathrm{CH}_{2}\right), 2.41\left(\mathrm{~s}, 3 \mathrm{H}, \mathrm{CH}_{3}\right), 2.45$ (s, 3H, m$\left.\mathrm{CH}_{3}\right), 7.22-7.53(\mathrm{~m}, 4 \mathrm{H}, \mathrm{ArH}), 8.3(\mathrm{~s}, 1 \mathrm{H}, \mathrm{Ar}-\mathrm{OH}), 10.6(\mathrm{~s}, 1 \mathrm{H}, \mathrm{Ar}-$ $\mathrm{OH}), 11.15$ (b, 1H, NH), 12.61 (b, 1H, NH). Anal. calcd. for $\mathrm{C}_{38} \mathrm{H}_{46} \mathrm{O}_{4} \mathrm{~N}_{12}$ : C, 62.10; H, 6.23; N, 22.88. Found: C, 61.89; H, $6.18 ; \mathrm{N}, 22.85 \%$.
4-[3'-Methyl-4'-(o-methoxyphenylazo)-1'H-pyrazole-5'ylazo]-3,5-[4,4'-dihexyl-1,1',3,3'-tetrahydroxy-diphenylazo]-1Hpyrazole (5h): Red. Yield: 84\%. M.p.: 183-184 ${ }^{\circ} \mathrm{C}$. FT-IR (KBr, $\left.\mathrm{cm}^{-1}\right)$ : 3467, $3456(2 \mathrm{OH}), 3284,3201(2 \mathrm{NH}), 3097(\mathrm{Ar}-\mathrm{H})$ 2989 (Ar-H). ${ }^{1} \mathrm{H}$ NMR $\left(400 \mathrm{MHz}, \mathrm{DMSO}-d_{6}, \delta, \mathrm{ppm}\right): 0.86(\mathrm{t}, 3 \mathrm{H}$, $\left.\mathrm{CH}_{3}\right), 1.41-1.67\left(\mathrm{~m}, 2 \mathrm{H}, \mathrm{CH}_{2}\right), 2.46\left(\mathrm{~s}, 3 \mathrm{H}, \mathrm{CH}_{3}\right), 3.91$ (s, 3H, o$\left.\mathrm{OCH}_{3}\right)$, 7.18-7.52 (m, 4H, ArH), 7.9 (s, $\left.1 \mathrm{H}, \mathrm{Ar}-\mathrm{OH}\right), 11.0(\mathrm{~s}, 1 \mathrm{H}$, Ar-OH), 10.99 (b, 1H, NH), 12.56 (b, 1H, NH). Anal. Calcd. for $\mathrm{C}_{38} \mathrm{H}_{46} \mathrm{O}_{5} \mathrm{~N}_{12}$ : C, 60.8; H, 6.10; N, 22.40. Found: $\mathrm{C}, 60.50 ; \mathrm{H}, 5.89$; N, $22.31 \%$.

4-[3'-Methyl-4'-(o-chlorophenylazo)-1'H-pyrazole-5'-ylazo]3,5[4,4'-dihexyl-1,1',3,3'-tetrahydroxy-diphenylazo]-1H-pyrazole (5i): Yellowish Orang. Yield: 85\%. M.p.: $235-236^{\circ} \mathrm{C}$. FT-IR (KBr, $\left.\mathrm{cm}^{-1}\right):$ 3479, $3465(2 \mathrm{OH}), 3283,3201(2 \mathrm{NH}), 3081(\mathrm{Ar}-\mathrm{H})$, 2977 (Ar-H). ${ }^{1} \mathrm{H}$ NMR $\left(400 \mathrm{MHz}, \mathrm{DMSO}-d_{6}, \delta, \mathrm{ppm}\right): 0.88(\mathrm{t}, 3 \mathrm{H}$, $\left.\mathrm{CH}_{3}\right), 1.49-1.89\left(\mathrm{~m}, 2 \mathrm{H}, \mathrm{CH}_{2}\right), 2.48\left(\mathrm{~s}, 3 \mathrm{H}, \mathrm{CH}_{3}\right), 7.40-7.66(\mathrm{~m}$, $4 \mathrm{H}, \mathrm{ArH}), 8.4$ (s, 1H, Ar-OH), 10.7 (s, $1 \mathrm{H}, \mathrm{Ar}-\mathrm{OH}), 11.12(\mathrm{~b}, 1 \mathrm{H}$ $\mathrm{NH}), 12.65$ (b, $1 \mathrm{H}, \mathrm{NH}$ ). Anal. calcd. for $\mathrm{C}_{37} \mathrm{H}_{43} \mathrm{O}_{4} \mathrm{~N}_{12} \mathrm{Cl}$ : C, 58.88; H, 5.70; N, 22.28. Found: C, 58.80; H, 5.63; N, 22.23\%.

4-[3'-Methyl-4'-(o-methylphenylazo)-1'H-pyrazole-5'-ylazo]3,5-[4,4'-dihexyl-1,1',3,3'-tetrahydroxy-diphenylazo]-1H-pyrazole (5j): Redish Brown. Yield: 72 \%. M.p.: 221-222 C. FT-IR (KBr, $\left.\mathrm{cm}^{-1}\right)$ : 3497, $3486(2 \mathrm{OH}), 3288,3198(2 \mathrm{NH}), 3093(\mathrm{Ar}-\mathrm{H})$, $2991(\mathrm{Ar}-\mathrm{H}) .{ }^{1} \mathrm{H}$ NMR $\left(400 \mathrm{MHz}, \mathrm{DMSO}-d_{6}, \delta, \mathrm{ppm}\right): 0.90(\mathrm{t}, 3 \mathrm{H}$, $\left.\mathrm{CH}_{3}\right), 1.35-1.76\left(\mathrm{~m}, 2 \mathrm{H}, \mathrm{CH}_{2}\right), 2.44\left(\mathrm{~s}, 3 \mathrm{H}, \mathrm{CH}_{3}\right), 2.59(\mathrm{~s}, 3 \mathrm{H},-$ $\left.\mathrm{CH}_{3}\right)$, 7.26-7.53 (m, 4H, ArH), 8.8 (s, 1H, Ar-OH), 11.2 (s, 1H, Ar$\mathrm{OH}), 11.09$ (b, 1H, NH), $12.58(\mathrm{~b}, 1 \mathrm{H}, \mathrm{NH})$. Anal. calcd. for $\mathrm{C}_{38} \mathrm{H}_{46} \mathrm{O}_{4} \mathrm{~N}_{12}$ : C,62.10; $\mathrm{H}, 6.23 ; \mathrm{N}, 22.88$. Found: C, 61.81; H, 6.19; $\mathrm{N}, 22.84 \%$.

\subsection{Antimicrobial activity of heterocyclic tetraazo dyes 5a- $5 \mathbf{j}$}

The antimicrobial activities of the newly synthesized compounds were evaluated using the micro broth dilution method [27] against a panel of eight microorganism species. The origin of microbial strains are Bacillus subtilis (NRRL B3711), Staphylococcus aureus (ATCC 25923), Escherichia coli (ATTC 25922), Proteus vulgaris (NRRL B-123), Candida albicans (NRRL Y-2983), Candida glabrata as yeasts. Stock solutions of synthesized compounds were diluted in DMSO to give serial decreasing dilutions ranging from 4 to $0.0009 \mathrm{mg} / \mathrm{mL}$. The dilutions were sterilized by filtration through $0.45 \mu \mathrm{m}$ millipore filters and were transferred to 96-well microtitre plates. 


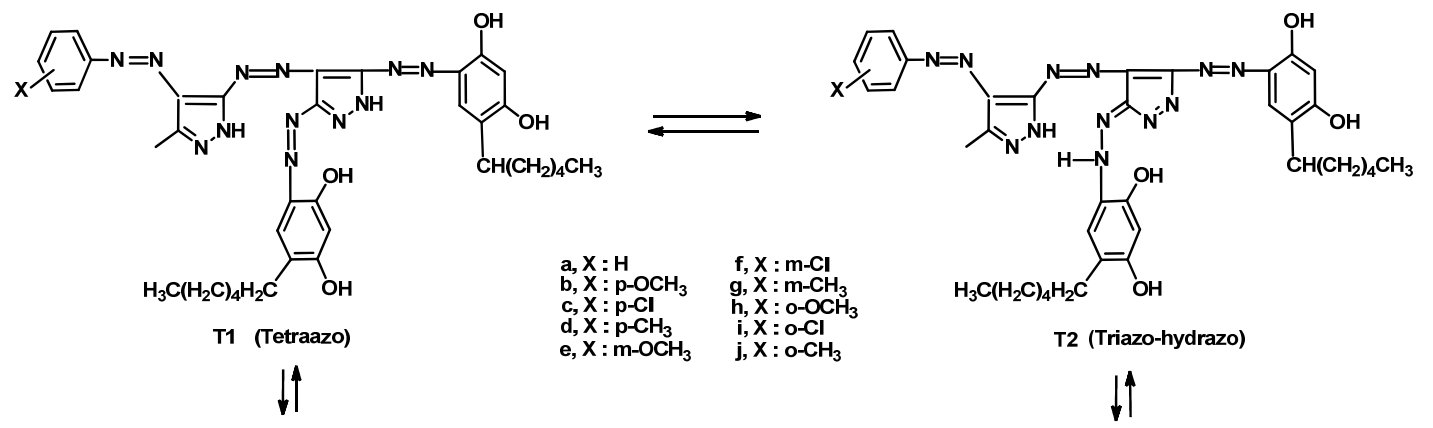

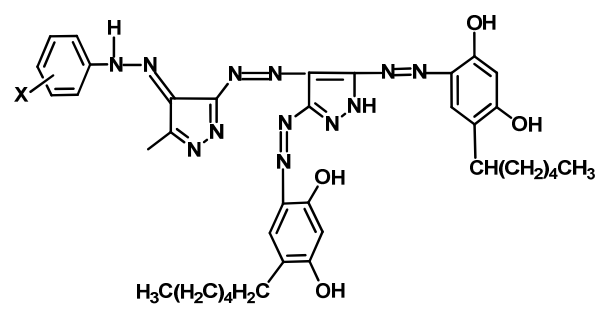

T3 (Hydrazo-triazo)

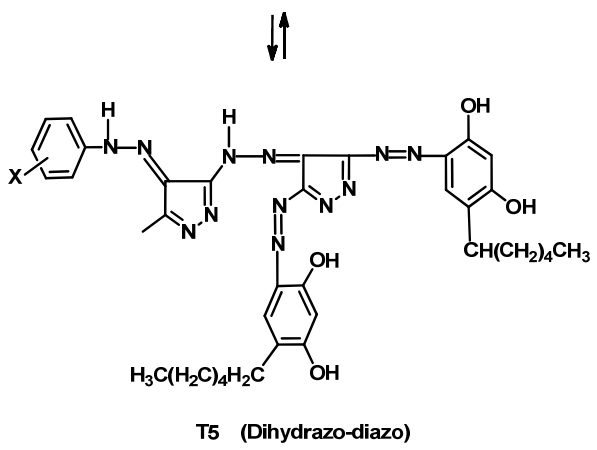

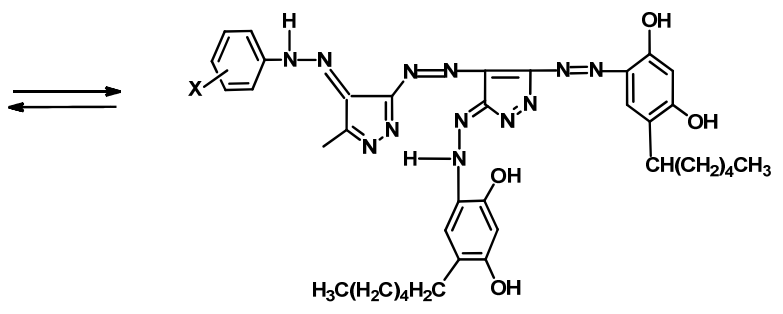

T4 (Dihydrazo-diazo)

$\downarrow \uparrow$

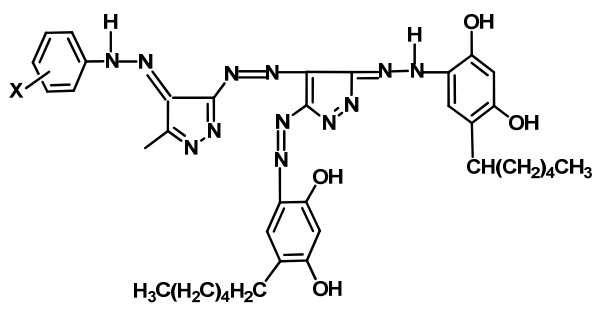

T6 (Dihydrazo-diazo)

Figure 1. Tautomeric equilibriums of dyes $\mathbf{5 a - 5 j}$.

Overnight grown microbial suspensions adjusted to McFarland 0.5 standard solutions were used as inoculants. A $100 \mu \mathrm{l}$ from each microorganism suspension was transferred into the wells. The well containing media, sterile distilled water and inoculums were used for positive growth control. The minimal inhibitory concentration (MIC) values were determined after incubation at $310.15 \mathrm{~K}$ for $18-24 \mathrm{~h}$. The MIC values were defined as the lowest compound concentration where absence of growth was recorded. Each test was repeated at least twice for all microorganisms. Streptomycin and fluconazole were used as reference antibiotics for bacteria and yeasts, respectively. All of the antimicrobial activity studies were performed in triplicate.

\section{Results and discussion}

\subsection{Spectral characteristics and tautomerism}

Tetraazo dyes $\mathbf{5 a - 5 j}$ can exist in six possible tautomeric forms, namely the Tetraazo form T1, the triazo-hydrazo form T2, the hydrazo-triazo form T3, the dihydrazo-diazo form T4, T5 and the dihydrazo-diazo form T6 as shown in (Figure 1). The FT-IR spectra of dyes $\mathbf{5 a - 5 j}$ showed intense intense two imino (NH) bands at 3294-3144 $\mathrm{cm}^{-1}$. The other $\lambda_{\max }$ values of $3101-3022 \mathrm{~cm}^{-1}$ (aromatic C-H) and 2994-2963 $\mathrm{cm}^{-1}$ (aliphatic C-H) were recorded.
${ }^{1} \mathrm{H}$ NMR spectra of dyes $\mathbf{5 a - 5 j}$ showed four broad peaks at 12.75-10.23 ppm (NH), 11.20-9.30 ppm (NH) and two broad peaks at 7.9-8.9 ppm (OH), 10.5-11.2 ppm (OH), 0.86-0.96 ppm $\left(\mathrm{CH}_{3}\right), 1.24-1.89 \mathrm{ppm}\left(\mathrm{CH}_{2}\right)$, respectively. The other $\delta$ values of 2.48-2.40 ppm $\left(\mathrm{CH}_{3}\right)$ and 8.35-6.98 ppm (aromatic $\mathrm{H}$ ) were recorded.

These results suggest that dyes $\mathbf{5 a - 5 j}$ is present as one of the tautomeric forms in DMSO and the solid state. Previously, we established that the tautomeric structure of pyrazole dyes in the solid state and solution medium using FT-IR and ${ }^{1} \mathrm{H}$ NMR. The spectral data generally lead to the conclusion that the tautomeric equilibrium of these dyes was in favour of the hydrazo form [28-30]. These suggest that these dyes are predominantly in triazo-hydrazo form (T2), (T3) or dihydrazodiazo form (T4), (T5) and (T6) in the solid state and DMSO.

\subsection{Solvent effects on UV-Vis spectra}

The UV-Vis absorption spectra of dyes $\mathbf{5 a}-\mathbf{5 j}$ were recorded over the range of $\lambda$ between 300 and $700 \mathrm{~nm}$, using a variety of solvents in concentrations $\left(10^{-6}-10^{-8} \mathrm{M}\right)$ and the results are summarized in (Table 1). The visible absorption spectra of the dyes did not correlate with the polarity of solvent.

Dyes 5a-5j gave a maximum absorption peak in all used solvents. This result suggests that dyes $\mathbf{5 a - 5} \mathbf{j}$ is present in a single tautomeric form in all used solvents. 
Table 1. Influence of solvent on $\lambda_{\max }(\mathrm{nm})$ of dyes $\mathbf{5 a}-\mathbf{5} \mathbf{j}$.

\begin{tabular}{|c|c|c|c|c|c|c|}
\hline Dye no & DMSO & DMF & Acetonitrile & Methanol & Acetic acid & Chloroform \\
\hline $5 a$ & 473 & 468 & 454 & 422 & 437 & 444 \\
\hline $5 b$ & 467 & 464 & 455 & 420 & 432 & 440 \\
\hline $5 c$ & 503 & 505 & 459 & 437 & 449 & 455 \\
\hline $5 d$ & 457 & 449 & 436 & 408 & 406 & 432 \\
\hline $5 e$ & 472 & 463 & 452 & 414 & 416 & 445 \\
\hline $5 \mathrm{f}$ & 483 & 482 & 463 & 423 & 422 & 456 \\
\hline $5 \mathrm{~g}$ & 472 & 463 & 453 & 422 & 418 & 445 \\
\hline $5 \mathrm{~h}$ & 475 & 466 & 455 & 429 & 427 & 458 \\
\hline $5 \mathrm{i}$ & 487 & 476 & 466 & 433 & 428 & 457 \\
\hline $5 j$ & 467 & 465 & 447 & 403 & 414 & 440 \\
\hline Dye no & Methanol & Methanol + KCl & Methanol + HCl & Chloroform & Chloroform + Piperidine & Acetic acid \\
\hline $5 a$ & 473 & 468 & 454 & 422 & 437 & 444 \\
\hline $5 b$ & 467 & 464 & 455 & 420 & 432 & 440 \\
\hline $5 c$ & 503 & 505 & 459 & 437 & 449 & 455 \\
\hline $5 \mathrm{~d}$ & 457 & 449 & 436 & 408 & 406 & 432 \\
\hline $5 e$ & 472 & 463 & 452 & 414 & 416 & 445 \\
\hline $5 f$ & 483 & 482 & 463 & 423 & 422 & 456 \\
\hline $5 \mathrm{~g}$ & 472 & 463 & 453 & 422 & 418 & 445 \\
\hline $5 \mathrm{~h}$ & 475 & 466 & 455 & 429 & 427 & 458 \\
\hline $5 i$ & 487 & 476 & 466 & 433 & 428 & 457 \\
\hline $5 j$ & 467 & 465 & 447 & 403 & 414 & 440 \\
\hline
\end{tabular}

It was observed that in DMSO, DMF and acetonitrile, $\lambda_{\max }$ of dyes $\mathbf{5 a}-\mathbf{5} \mathbf{j}$ shifted bathochromically with respect to the $\lambda_{\max }$ in chloroform (e.g. for dye $\mathbf{5 d} \lambda_{\max }$ is $432 \mathrm{~nm}$ in chloroform, 457 $\mathrm{nm}$ in DMSO, $449 \mathrm{~nm}$ in DMF and $436 \mathrm{~nm}$ in acetonitrile) (Figure 2). But, when we compare the bathochromic shifts of $\lambda_{\max }$ of dyes $\mathbf{5 a - 5} \mathbf{j}$ in acetonitrile are less than in DMSO and DMF solvent. On the other hand, it was observed that in acetic acid and methanol, $\lambda_{\max }$ of dyes $\mathbf{5 a - 5 j}$ shifted hypsochromically with respect to the $\lambda_{\text {max }}$ in chloroform (e.g. for dye $5 \mathbf{b} \lambda_{\text {max }}$ is $440 \mathrm{~nm}$ in chloroform, $432 \mathrm{~nm}$ in acetic acid and $420 \mathrm{~nm}$ in methanol) (Figure 3). It was also observed that hypsochromic shifts of $\lambda_{\max }$ of dyes $\mathbf{5 a - 5 c}$ and $\mathbf{5 j}$ in acetic acid are less than hypsochromic shifts of $\lambda_{\max }$ of dyes $\mathbf{5 a - 5 c}$ and $\mathbf{5 j}$ in methanol. Hypsochromic shifts of $\lambda_{\max }$ of dyes $\mathbf{5 d - 5 i}$ in acetic acid and methanol are similar.

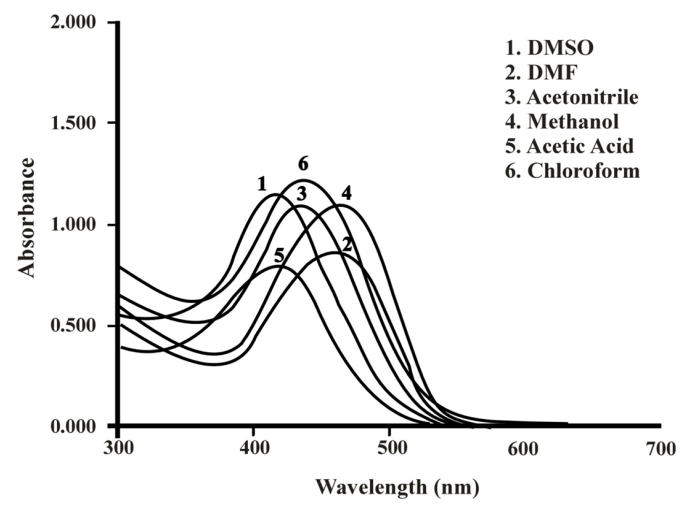

Figure 2. Absorption spectra of dye $\mathbf{5 d}$ in various solvent.

\subsection{Acid and base effects on UV-Vis spectra}

The effects of acid and base on the absorption of dye solutions were investigated and the results are shown in (Table 2). The absorption spectra of the dyes in methanol were also quite sensitive to the addition of base (potassium hydroxide, $0.1 \mathrm{M}$ ), with $\lambda_{\max }$ of dyes $\mathbf{5 a - 5 j}$ showing bathochromic shifts and absorption curves of the dyes resembled those in DMSO and DMF (Figure 3). This result suggests that these dyes are present in a different tautomeric form in methanol+KOH than that in methanol and this tautomeric form resembled those in DMSO and DMF.
When piperidine was added to dye solutions in chloroform, $\lambda_{\max }$ of dyes $\mathbf{5 a - 5 j}$ did not change significantly except for dye $\mathbf{5 c}$ (Figure 4). $\lambda_{\max }$ of the dye $\mathbf{5 c}$ showed bathochromic shift when a small amount of piperidine was added to dye $\mathbf{5 c}$ solution in chloroform.

When hydrochloric acid (0.1 M) was added to dye solutions in methanol, $\lambda_{\max }$ of dyes $\mathbf{5 a - 5 c}$ and $\mathbf{5 j}$ showed little bathochromic shifts with respect to the $\lambda_{\max }$ in methanol and the absorption spectra of dyes resembled those in acetic acid (Figure 5). It was also observed that when hydrochloric acid $(0.1 \mathrm{M})$ was added to dye solutions in methanol, $\lambda_{\max }$ of dyes 5d-5i did not change significantly.

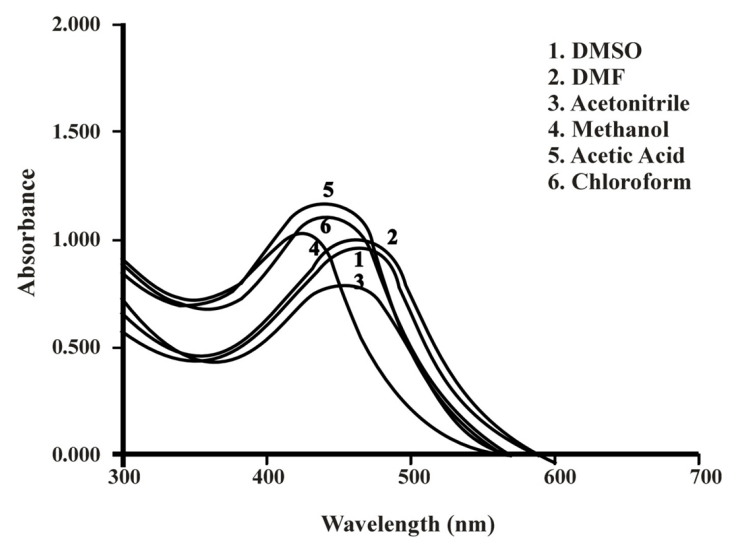

Figure 3. Absorption spectra of dye $5 \mathrm{~b}$ in various solvent.

\subsection{Substituent effects on UV-Vis spectra}

As seen in (Table 1), generally, electron-accepting chloro groups in all positions for dyes $\mathbf{5 c}, \mathbf{5 f}$ and $\mathbf{5 i}$ cause bathochromical shifts in all used solvents when compared with dye 5a. $\boldsymbol{\lambda}_{\max }$ of dyes $\mathbf{5 f}$ and $\mathbf{5 i}$ in acetic acid hypsochromically shifted when compared with $\lambda_{\max }$ of dye $\mathbf{5 a}$ in acetic acid. Electron-donating methoxy and methyl groups in para position for dyes $\mathbf{5 b}$ and $\mathbf{5} \mathbf{d}$ and methyl group in ortho position for dye 5j because hypsochromical shifts in all used solvents when compared with dye $\mathbf{5 a}$. Visible absorption spectra of dyes $\mathbf{5 e}$, $\mathbf{5 g}$ and $\mathbf{5 h}$ did not regularly change with the substituent effect in all used solvents when compared with dye $\mathbf{5 a}$. 
Table 3. Biological activities of dyes $\mathbf{5 a}-\mathbf{5} \mathbf{j}(\mu \mathrm{g} / \mathrm{mL})$.

\begin{tabular}{|c|c|c|c|c|c|c|}
\hline \multirow[b]{2}{*}{ Dye no } & \multicolumn{4}{|c|}{ Bacteria } & \multicolumn{2}{|c|}{ Yeasts } \\
\hline & $\begin{array}{l}\text { Bacillus } \\
\text { subtilis }\end{array}$ & $\begin{array}{c}\text { Staphylococcus } \\
\text { aureus }\end{array}$ & $\begin{array}{c}\text { Escherichia } \\
\text { coli }\end{array}$ & $\begin{array}{l}\text { Proteus } \\
\text { vulgaris }\end{array}$ & $\begin{array}{l}\text { Candida } \\
\text { albicans }\end{array}$ & $\begin{array}{l}\text { Candida } \\
\text { glabrata }\end{array}$ \\
\hline$\overline{5 a}$ & 125 & 125 & 1000 & 1000 & 500 & 3.90 \\
\hline $5 b$ & 2000 & 1000 & 2000 & 1000 & 2000 & 3.90 \\
\hline $5 c$ & $>4000$ & 2000 & 1000 & $>4000$ & 3.90 & 3.90 \\
\hline $5 d$ & 1000 & 5000 & 1000 & 1000 & 1000 & 1000 \\
\hline $5 e$ & 1000 & 1000 & 2000 & 2000 & 3.90 & 3.90 \\
\hline $5 f$ & 1000 & 2000 & 1000 & 2000 & 3.90 & 3.90 \\
\hline $5 g$ & 2000 & 1000 & 1000 & 1000 & 1000 & 1000 \\
\hline $5 \mathrm{~h}$ & 1000 & 2000 & 2000 & 2000 & 2000 & 2000 \\
\hline $5 i$ & 2000 & 2000 & 1000 & 2000 & 2000 & 1000 \\
\hline $5 j$ & 2000 & 2000 & 1000 & 2000 & 2000 & 2000 \\
\hline Streptomycin & 15.62 & 0.97 & 3.90 & 31.25 & - & - \\
\hline Fluconazole & - & - & - & - & 3.90 & 7.81 \\
\hline
\end{tabular}

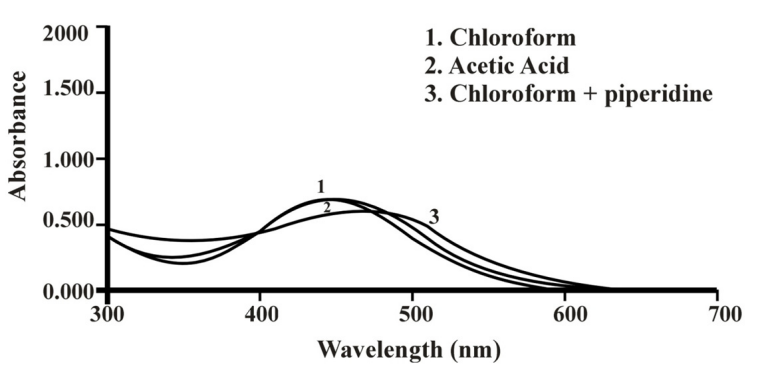

Figure 4. Absorption spectra of dye $\mathbf{5 c}$ in different solutions.

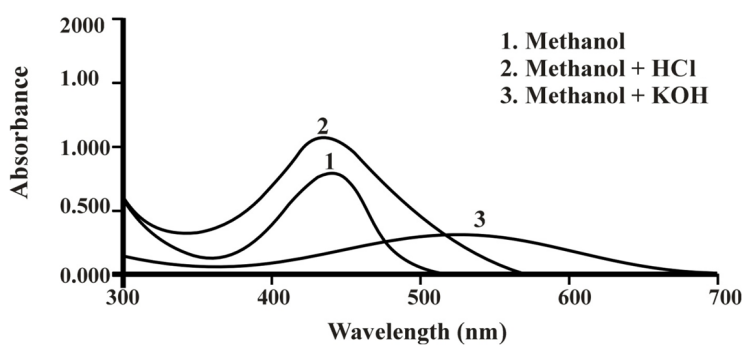

Figure 5. Absorption spectra of dye $\mathbf{5 c}$ in basic solutions.

\subsection{Antimicrobial activity of the synthesized dyes}

Although, there are some reports about antimicrobial activity of monoazo dyes [31-33], research on biological activity of disazo dyes has just started [34]. In the current study, in vitro antimicrobial activities of the newly synthesized disazo dyes were also reported. The results of antimicrobial screening of the synthesized compounds and standard antibiotics are given in (Table 3).

The MIC values of the dyes are generally within the range $3.90-2000 \mu \mathrm{g} / \mathrm{mL}$ against all tested microorganisms. Results showed that none of the synthesized dyes have important antibacterial activities when compared with control antibiotic, streptomycin. Not only gram negative but also Gram-positive bacteria were resistant to all synthesized dyes with the exception of dye $\mathbf{5 a}$. This compound showed activity against $B$. subtilis and S. aureus at the dose of $125 \mathrm{mg} / \mathrm{mL}$.

In contrast, different levels of antifungal activities were observed for some dyes against the yeasts. Dyes $\mathbf{5 a - 5 c}, \mathbf{5 e}$ and 5f exhibited stronger antifungal activity than not only other dyes but also fluconazole against $C$. glabrata. Among the all tested dyes, 5c, 5e and $\mathbf{5 f}$ showed the highest antifungal activity against both the yeasts. These dyes had similar activity level with fluconazole against $C$. albicans. On the other hand, as an impressive result, active concentration of these dyes against C. glabrata was lower than fluconazole. The rest of dyes had no important inhibitory activity against the yeasts $C$. albicans and C. glabrata.
In previous studies about antimicrobial activity of monoazo or disazo dyes, synthesized compound had antibacterial activity $[35,36]$. It was reported weak or no antimicrobial activity for these compounds against fungi [37]. However, in the present study, synthesized dyes were determined more active against fungal organisms. Therefore the results obtained in the present study can be accepted as promising to develop new antifungal compound(s).

\section{Conclusion}

A series of novel disazo dyes $\mathbf{4 a - 4} \mathbf{j}$ based on heterocyclic rings were synthesized by heating pyrazolylhydrazonomalono nitriles with hydrazine monohydrate and disazo dyes $\mathbf{4 a - 4 j}$ were further diazotized and coupled with 4-hexylbenzene-1,3diol to produce the tetraazo dyes $\mathbf{5 a - 5 j}$. All newly synthesized tetraazo dyes were well characterized and acid-base influence on the wavelength of maximum absorption have been studied. In the present paper, heterocyclic tetraazo dyes showed solvatochromic effects. When we compare the absorption maxima of such dyes in different solvent then it clearly indicate bathochromic shifts in DMSO and DMF rather than the other four solvents. It was also observed that the absorption spectra of these tetraazo dyes in methanol were quite sensitive to the addition of base.

Our study demonstrated clearly that, novel $\mathbf{5 c}$, 5e and $\mathbf{5 f}$ tetraazo dyes had significant antifungal activity when compared with control antibiotic, fluconazole. As a consequence, we can conclude that especially the newly synthesized 5c, 5e and $\mathbf{5 f}$ dyes could be lead for the development of new antifungal drugs.

\section{Acknowledgements}

The author is thankful to Mr. Ashok Chotalal Kapadia and Mr. Pradeep Natvarlal Mistry of Colortax (Private) Ltd., Surat, India for characterization of tetraazo dyes and Shashikant Babarbhai Patel of Sumit-Industry, Pandesara, Surat, India for providing standard of analysis work.

\section{References}

[1]. Elnagdi, M. H.; Sallam, M. M. M; Fahmy, H. M.; Ibrahim, S. A. M.; Elias, M. A. M. Helv. Chim. Acta 1976, 59(2), 551-557.

[2]. Elnagdi, M. H.; Elgemeie, G. E. H.; Abdelaal, F. A. E. Heterocycles 1985 23(12), 3121-3153.

[3]. Freeman, F. Synthesis-Stuttgart 1981, 12, 925-954.

[4]. Tominaga, Y.; Honkawa, Y.; Hara, M.; Hosomi, A. J. Heterocycl. Chem. 1990, 27(3), 775-783.

[5]. Mohareb, R. M.; Sherif, S. M.; Gaber, H. M.; Ghabrial, S. S.; Aziz, S. I. Hetero. Chem. 2004, 15(1), 15-20.

[6]. Hanefeld, U.; Rees, C. W.; White, A. J. P.; Williams, D. J. J. Chem. Soc Perkin Trans. 1996, 13, 1545-1552.

[7]. Ho, Y. W. Dyes Pigm. 2005, 64(3), 223-230

[8]. Karcl, F.; Demirçalı, A. Dyes Pigm. 2007, 74(2), 288-297.

[9]. Elagamey, A. G. A.; Mohamed, F.; Eltaweel, A. A. J. Prak. Chem. 1991 333(2), 333-338. 
[10]. Karcl, F.; Sener, I.; Demircalı, A.; Burukoglu, N. Color. Technol. 2006, 122, 264-269.

[11]. Karcl, F.; Karcl, F. Dyes Pigm. 2008, 76(1), 97-103.

[12]. Karcı, F.; Demircall, A.; Karcı, F.; Kara, I.; Ucun, F. J. Mol. Struct. 2009, 935(1-3), 19-26.

[13]. Senga, K.; Novinson, T.; Springer, R. H.; Rao, R. P.; Obrian, D. E.; Robins, R. K. J. Med. Chem. 1975, 18(3), 312-314.

[14]. Dias, L. R. S.; Alvim, M. J.; Freitas, A. C. C.; Barreiro, E. J.; Miranda, A. L. P. Pharm. Acta Helv. 1994, 69(3), 163-169.

[15]. Lyga, J. W.; Patera, R. M.; Plummer, M. J.; Halling, B. P.; Yuhas, D. A. Pestic. Sci. 1994, 42(1), 29-36.

[16]. Genin, M. J.; Biles, C.; Keiser, B. J.; Poppe, S. M.; Swaney, S. M.; Tarpley, W. G. J. Med. Chem. 2000, 43(5), 1034-1040.

[17]. Ertan, N. Dyes Pigm. 1999, 44(1), 41-48.

[18]. Tsai, P. C.; Wang, I. J. Dyes Pigm. 2005, 64(3), 259-264.

[19]. Penchev, A.; Simov, D.; Gadjev, N. Dyes Pigm. 1991, 16(1), 77-81.

[20]. Sokolwska-Gajda, J. Dyes Pigm. 1991, 15(4), 239-245.

[21]. Sokolwska-Gajda, J. Dyes Pigm. 1992, 19(2), 149-156.

[22]. Yen, M. S.; Wang, I. J. Dyes Pigm. 2004, 62(2), 173-180.

[23]. Yen, M. S.; Wang, I. J. Dyes Pigm. 2004, 63(1), 1-9.

[24]. Desai, C. K.; Desai, K. R. High Perform. Polym. 2000, 12, 315-322.

[25]. Wilkinson, S. C.; Higham, S. M.; Ingram, G. S.; Edgar, W. M. Adv. Dent. Res. 1997, 11, 515-522.

[26]. Singha, K.; Singha, S.; Taylor, J. A. Dyes Pigm. 2002, 54, 189-196.

[27]. Koneman, E. W.; Allen, S. D.; Winn, W. C. Colour atlas and textbook of diagnostic microbiology, Philadelphia, Lippincott Raven Publishers, 1997, 822-824

[28]. Karcl, F.; Karcl, F. Dyes Pigm. 2008, 76(1), 147-157.

[29]. Karcl, F.; Ertan, N. Dyes Pigm. 2002, 55(2-3), 99-108

[30]. Karcl, F. Color. Technol. 2005, 121(5), 275-280.

[31]. Ozturk, A. Abdullah M.I. Sci. Total Environ. 2006, 358 (1-3), 137-142.

[32]. Liu, S.; Ma, J.; Zhao, D. Dyes Pigm. 2007, 75(2), 255-262.

[33]. Odabasoglu, M.; Albayrak, C.; Ozkanca, R.; Akyan, F. Z.; Lonecke, P. J. Mol. Struct. 2007, 840(1-3), 71-89.

[34]. Seferoglu, Z.; Ertan, N.; Yllmaz, E.; Uraz, G. Color. Technol. 2008, 24(1), 27-35.

[35]. Liu, J.; Sun, G. Dyes Pigm. 2008, 77(2), 380-386

[36]. Shindy, H. A.; El-Maghraby, M. A.; Eissa, F. M. Dyes Pigm. 2006, 70(2), 110-116.

[37]. Abd El-Aal, R. M.; Younis, M. Dyes Pigm. 2004, 60(3), 205-214. 